\title{
Composite Restorative Resins
}

Part 3 Cytotoxicity Test to Mouse Fibroblasts in Culture of UV and Visible Light-activated Composite Resins

\author{
Katsuichiro INOUE*, Hiroyuki ARIKAWA*, Koichi FUJII*, Akira NIIHARA*, \\ Ryuichiro FUJITA*, Gakuji TSUKADA*, Kayoko KUROKI**, Tomoko OKA*** and \\ Choji UCHIYAMA*** \\ *Department of Dental Materials Science, Kagoshima University Dental School, \\ 1208-1 Usuki, Kagoshima 890, Japan \\ **Department of Dental Pharmacology \\ ***Department of Oral Bacteriology, Kyushu Dental College, 2-6-1, \\ Manazuru, Kokurakita-ku, Kitakyushu 803, Japan
}

Received on January 28,1988

Accepted on March 28, 1988

\footnotetext{
Agar overlay cytotoxicity tests of 18 commercial light-activated composite resins were carried out, using L929 mouse fibroblasts in culture, and the difference of adverse reaction to L-cell among certain materials was compared. In addition, the unreacted substances in the cured material, such as Bis-GMA and Triethyleneglycol dimethacrylate, were measured using a high performance liquid chromatograph, and the relationship between the amount of unreacted substance and the injured toxic area $\left(\mathrm{cm}^{2}\right)$ of L-cell was presented and discussed. From the results, with the exception of a few materials, adequate correlation between both factors was estimated. The injured area of L-cell was enlarged as the unreacted substances in the cured material increased.
}

Key words: Light-activated composite resin, Cytotoxicity, Unreacted substance

\section{INTRODUCTION}

Recently, di-acrylate, such as Bis-GMA, has been used extensively as a base material for composite restorative resin. However, it has been suggested that the unreacted substance in the cured material may cause an adverse tissue reaction, which becomes a serious problem in clinical application. The purpose of this investigation was to examine the unreacted substance in the cured materials and to investigate the effect of the unreacted substance on mouse fibroblasts in culture.

\section{MATERIALS AND METHODS}

The materials used in this investigation are listed together with manufacturer's name, batch number, color shade, exclusive light, exposure time and depth of cure in Table 1. All materials were polymerized into a rod shape $(5.0 \mathrm{~mm}$ in diameter and $2.0 \mathrm{~mm}$ hight) using a PTFE mold, according to the manufacturer's recommendation at a temperature of $23 \pm 0.5^{\circ} \mathrm{C}$, and then were used to measure the unreacted substance and for the cytotoxicity test on mouse fibroblasts in culture. 
Table 1 Materials and lights used

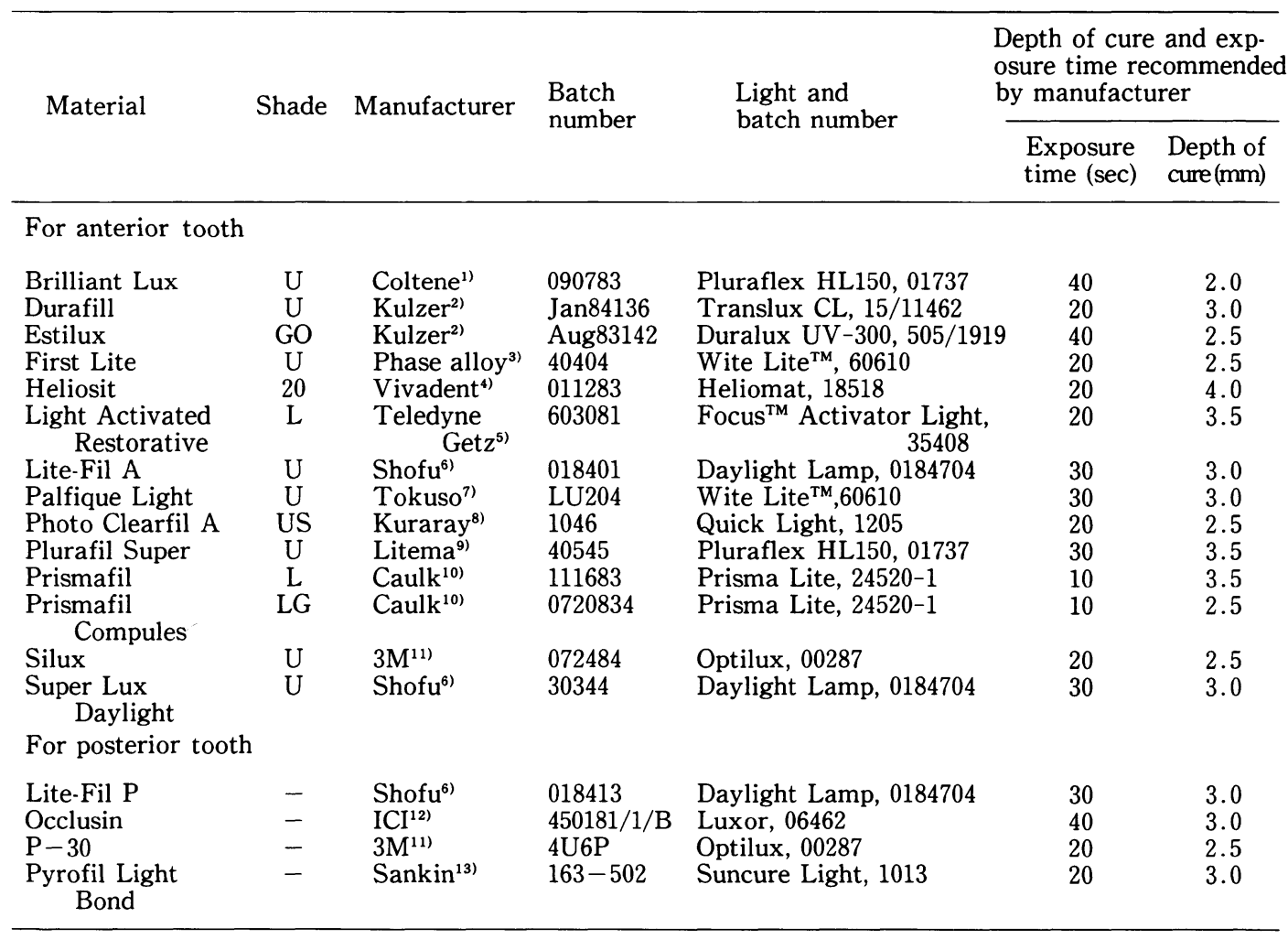

1) Altstaten, Switzerland ${ }^{2)}$ Homburg, West-Germany ${ }^{3)}$ Los Angeles, USA ${ }^{4)}$ Schaan,

Lichtenstein ${ }^{5)}$ Grove Village, USA ${ }^{6)}$ Kyoto, Japan ${ }^{7)}$ Tokuyama, Japan ${ }^{8)}$ Kurashiki, Japan

${ }^{9)}$ Barden-Barden, West-Germany ${ }^{10)}$ Milford, USA ${ }^{11)}$ St. Paul, USA ${ }^{12)}$ Macclcesfield, England

13) Osaka, Japan

1. Determination of unreacted substance in cured material ${ }^{1,2)}$.

Each material was ground for two hours using a mortar and pestle after polymerization and its powder $(0.05 \mathrm{~g})$ was weighed accurately and added immediately to Tetrahydrofuran $(10 \mathrm{ml})$. The amount of unreacted substance in the cured material was determined using a high performance liquid chromatograph (Shimadzu-Dupont, LC-3A), incorporating two steel columns (Shodex, GPC KF-801 and GPC KF-802). A sample of each solution (10 ml) was injected into the chromatograph and three measurements were made for each solution. In measuring the unreacted substance, the tetrahydrofuran solution of each material before setting was used for calibration purposes. The unreacted substance was calculated as the area under the curve at peak, produced by the material before and after setting. The percentage of unreacted substance in the tetrahydrofuran solution was converted to the unreacted substance content in the cured material $(0.05 \mathrm{~g})$ by calculating the total mass of unreacted substance in the tetrahydrofuran solution.

\section{Cytotoxicity test of composite resins ${ }^{3)}$}

The cytotoxicity test of the cured material was carried out using L929 mouse fibroblasts in culture. All materials were polymerized into a rod shape $(5 \mathrm{~mm}$ in diameter and $2.0 \mathrm{~mm}$ 


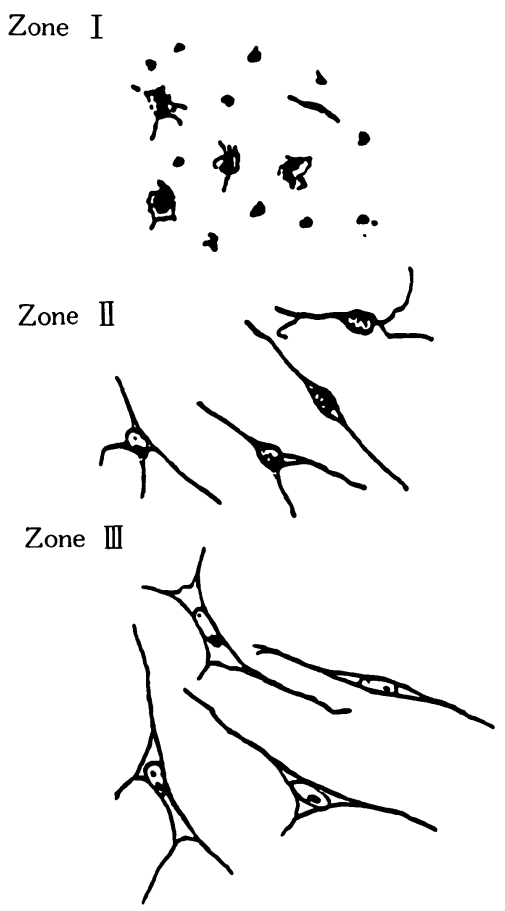

Fig. 1 Classification of morphological changes of L-cell which were dyed with Giemsa stain after 24-hours contact with material. zone I : Decomposed and rounded cells with dark nucleus, zone II : contracted cells, zone III : normal cells.

hight) and placed on the cells which were cultivated in advance on a glass cover slip. The contact time of the materials/to cells was 24 hours. The cells were dyed with Giemsa stain after removal of the material and the morphological changes that took place were investigated using a light microscope.

The extent of morphological change in the cells was classified into three zones as shown in Fig. 2. In addition, this measurement was also performed for the uncured materials before exposing them to light. In this case, an agar culture medium and material were covered with a black vinyl sheet and shielded completely from the light. The contact period for these materials/to cells was $2 \mathrm{~min}, 4$ hours and 24 hours.

\section{RESULTS AND DISCUSSION}

The percentage of unreacted substance in the cured material and the results of the cytotoxicity test are presented in Figs. 2 and 3, respectively. All materials, with the exception of Palfique Light, Prismafil, Prismafil Compules and Pyrofil Light Bond, indicated relatively weak cytotoxicity to the cells. Furthermore, among these materials, there was adequate correlation between the percentage of unreacted substance in the cured material and the area which appears toxic to the cells, as shown in Fig. 4. The coefficient of 


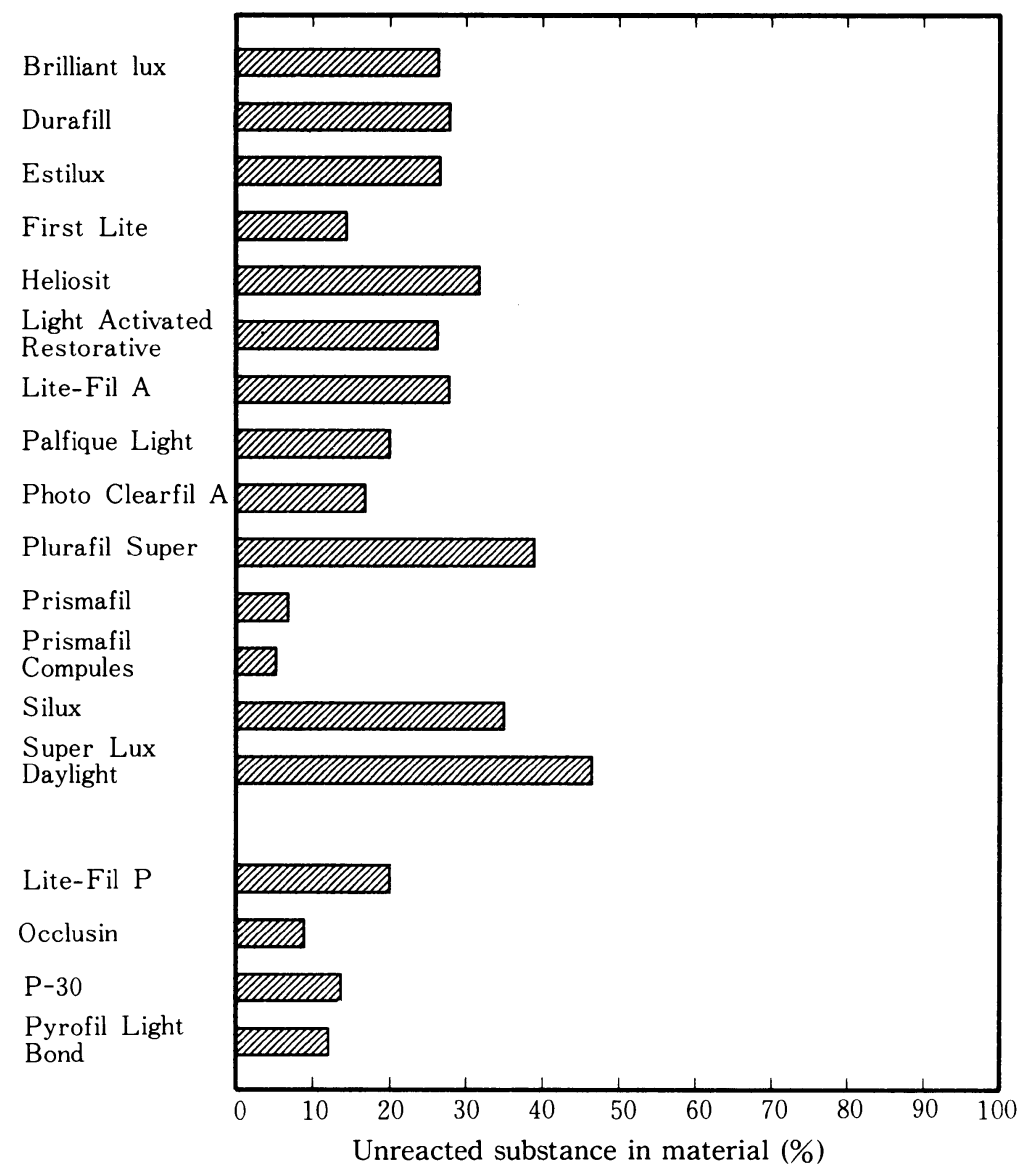

Fig. 2 Percentages of unreacted substance in cured material at 3 days after polymerization.

correlation was 0.728 for zone I and 0.726 for zone II. These results indicate that the cytotoxicity to cells increases with the increase of unreacted substance in the cured material. For Palfique Light, Prismafil, Prismafil Compules and Pyrofil Light Bond, the injured area of cells appeared markedly large, though the percentage of unreacted substance in the cured material was low.

Although the reason is presently unknown, it may be closely connected with the materials used in the manufacturing process of composite resin.

Particularly, for Palfique Light, zone I, where the decomposed cells and rounded cells with dark nucleus exists, the cells were not wholly observed. However, in zone II, which contains many contracted cells, cells were observed over a wider region than those of other materials, as shown in Fig. 3. This phenomenon is rather unusual and a matter of interest. In the contact test of $2 \mathrm{~min}$ for an uncured material before exposing it to light, no morphological change in cells were seen in any of the materials used. However, in the contact 


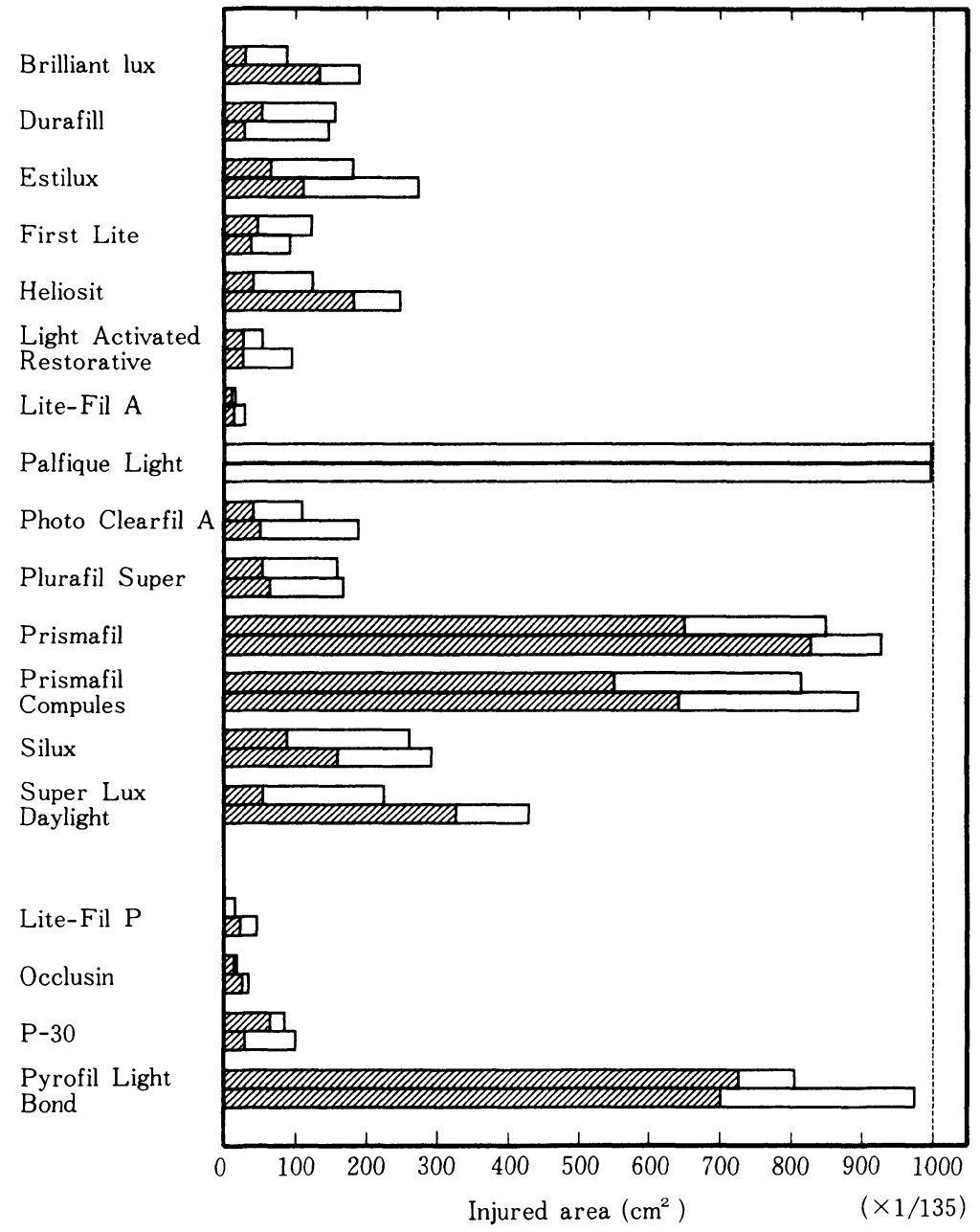

Fig. 3 Injured area of L-cell caused by contact with cured composite resins. upper parts : for $1.5 \mathrm{~mm}$ specimen thickness,

lower parts: for maximum specimen thickness (Table 1) recommended by manufacturer, (ख्य shows zone I and $\square$ shows zone II).

test for 4 hours and 24 hours, marked morphological changes of cells were observed. These results are shown in Fig. 5. The injured area of cells for four materials (Palfique Light, Prismafil, Prismafil Compules and Pyrofil Light Bond) became wider, compared with those of other materials. From these results, therefore, it follows considered that these four materials contain more substances that were soluble in the agar culture medium.

\section{CONCLUSION}

The agar overlay cytotoxicity tests of 18 commercial light-activated composite resins 


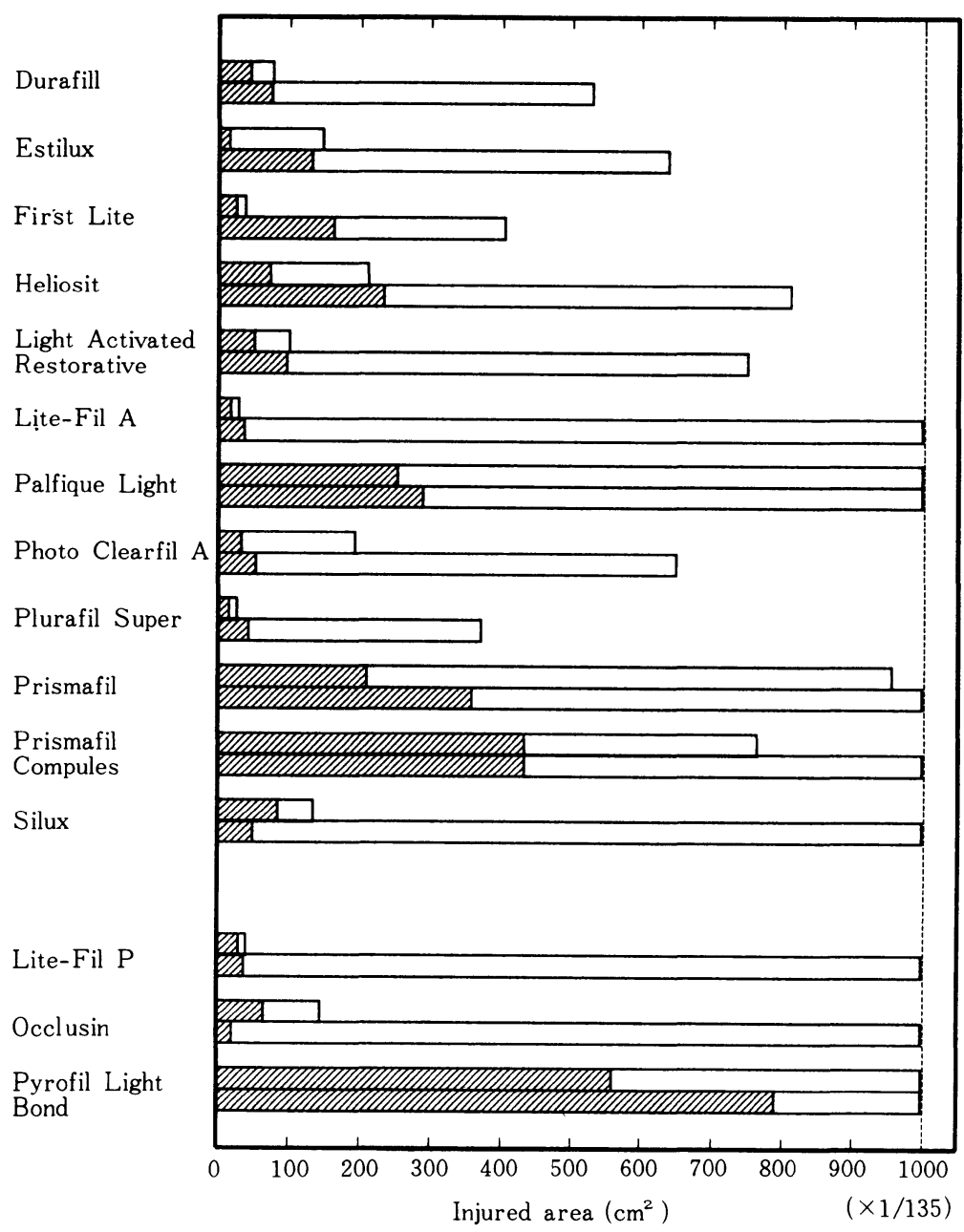

Fig. 5 Injured area of L-cell caused by contact with uncured composite resins before exposing to light. upper parts : contact with material for 4 hours, lower parts : contact with material for 24 hours. shows zone I and $\square$ shows zone II).

were carried out and the relationship between their results and the amount of unreacted substance in the cured material was investigated. The coefficient of correlation between the injured area of mouse fibroblasts in culture and the amount of unreacted substance in the cured material was 0.728 in zone I and 0.726 in zone II, respectively. In general, the injured area of cells expanded in accordance with the increase of unreacted substance in the cured material. However, a few materials which appeared to have relatively large injury to cells also existed among the commercial products, regardless of the amount of unreacted substance in the cured material. 


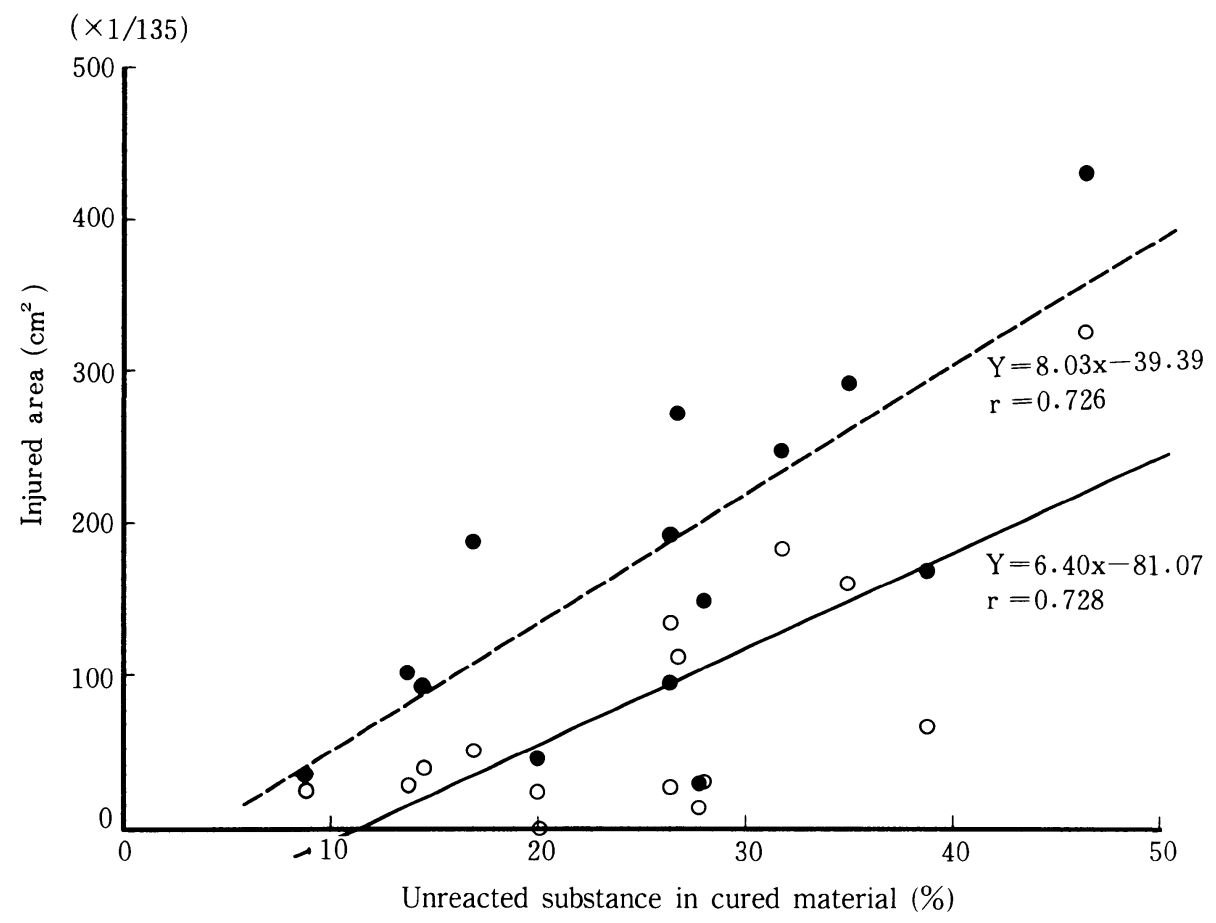

Fig. 4 Relationship between amount of unreacted substance in cured composite resins and injured area of $\mathrm{L}$-cell caused by them. ( $\bigcirc$ shows zone I and $\bigcirc$ shows zone II).

\section{REFERENCES}

1) Arikawa, H., Fujii, K., Kanie, T., Tabata, Y., Oku, J., Jyoshin, K., Inoue, K., Kuroki, K. and Uchiyama, C.: Composite restorative resins. Part 1 . Setting characteristics of UV and visible light-activated composite resins, Dent Mater J 5 (2) : 246-251, 1986.

2) Fujii, K., Ginya, K., Arikawa, H., Kanie, T., Jyoshin, K., Inoue, K., Kuroki, K. and Uchiyama, C.: Composite restorative resins. Part 2. Physical and mechanical properties of UV and visible lightactivated composite resins, Dent Mater J 5 (2) : 252-259, 1986.

3) Inoue, K., Miura, K., Funada, M., Ishizawa, S., Tabata, Y., Ginya, K., Niihara, A., Uchiyama, C. and Kuroki, K. : Physical and mechanical properties of light-activated composite resins, Dental Outlook 68 (4) : 799-808, 1986. (in Japanese) 
コンポジットレジン用レオメータにより 4 種類の市販 小窩裂溝填塞材の操作時間, 硬化時間を測定した。また, 人の抜去歯牙の小窩裂溝に填塞された材料の硬化中の温 度上昇を熱電対を用いて調へ, さらに, 高速液体クロマ トグラフを使って硬化後の末反応物質の分析を行った。

$23^{\circ} \mathrm{C}$ でのそれぞれの材料の操作時間は $0.52 \sim 1.09$ $\min$ の間であり,そしてまた $32^{\circ} \mathrm{C} て ゙ の$ 硬化時間は 0.91 1.38 minの間であった。0.5 mm の厚さで硬化さ
せた時, 髄室蓋から $1.2 \mathrm{~mm}$ 離れたデンチン部分での温 度上昇は $0.18 \sim 0.21^{\circ} \mathrm{C}$ の間であった。末反応物質は，硬 化前後のそれぞれの溶液で測定されたクロマトグラフの 面積比で計算され, $0.5 \mathrm{~mm}$ の厚さの試料では, それぞれ の材料で 19.7〜 $45.8 \%$ の範囲であった。 本実験中の小窩裂溝填塞材では, 硬化時の温度上昇の 歯髄に対する影響はほとんどないと思われる。

\title{
充てん用コンポジットレジンに関する研究 \\ 一第 3 報一 光重合型コンポジットレジンの L 細胞に対する毒性試験
}

\author{
井上勝一郎*, 有川裕之*, 藤井孝一*, 新原 明*, 藤田龍一郎 ${ }^{*}$ \\ 塚田岳司 ${ }^{*}$, 黒木賀代子**，岡 智子***，内山長司*** \\ *鹿児島大学歯学部歯科理工学講座 **九州歯科大学歯科薬物学講座 \\ ***九州歯科大学口腔細菌学講座
}

現在市販されている 18 種類の光重合型コンポジット レジンについて，マウス由来の培養細胞に対する各材料 の細胞毒性試験を行なった。細胞障害の程度は, 細胞死 滅を含む核濃染領域と細胞形質に萎縮がみられる領域の 2 領域にわけ，それぞれの領域の面積で表示した。また， 各材料の硬化物中に含まれる末反応物の量を高速液体》 ロマトグラフを用いて定量し, 未反応物量と細胞障害が みられる領域との関係を調べた。その結果，4種類の材 料(パルフィークライト, プリズマフィル, プリズマフィ
ルコンピュール，パイロフィルライトボイド）を除く他 の材料間では, 硬化体中の未反応物量と細胞障害を引き 起こす領域との間に相関がみられ，末反応物の増加に 伴って細胞障害を起こす領域が大きくなることがわかっ た。除外した 4 種類の材料については, 硬化体中の未反 応物量は少ないにもかかわらず, 細胞障害を起こす領域 が著しく大きくなっている。この理由については現在檢 討中である。

接着性ブリッジの耐久性に関する破壊力学的解析

—接着性ブリッジの設計要因が接着層でのき裂成長に与える影響 —

篠原直幸

\section{鹿児島大学歯学部歯科補綴学第 1 講座}

有限要素法にもとづく破壊力学的手法によって, 接着 性補経物の設計条件と接着材層に発生するき裂成長との 関係をエネルギー解放率 $g$ の概念を用いることにより 解析した。解析は接着材層でのき裂成長に伴うエネル ギ一解放率とクリティカルロードの值が, 水平的なき裂 長さ $a^{*}$, 安全率 $n$, メタルフレームの構造および金属の 厚さのファクターによりどの様に変化するかにより行 なった。解析の結果, $g$ はメ夕ルの厚みが増すと減少し,
$1.0 \mathrm{~mm}$ 以上では非常に小さくなった。また隣接面に ウィングを設定すると設定しない場合に比べ $g$ は小さ くなり, その差 $\Delta g$ はウィング長の半分程度で最大と なった。そして $\Delta g$ は, 金属厚みの増加に伴ない減少し た。結果とクリティカルロードを用いた考察により，接 着性補綴物の耐久性を向上させる為のブリッジの設計要 因について検討を行ない呈示した。 